\title{
An innovative endotracheal tube clamp for use in COVID-19
}

\author{
Miguel Jacob, MD · Ernesto Ruivo, MD · Inês Portela, MD • \\ João Tavares, MD $\cdot$ Miguel Varela, MD $\cdot$ Sofia Moutinho, MD • \\ Hugo Costa, MD · Daniel Nunez, MD
}

Received: 1 May 2020/Revised: 3 May 2020/Accepted: 3 May 2020/Published online: 11 May 2020

(C) Canadian Anesthesiologists' Society 2020

\section{To the Editor,}

The coronavirus disease (COVID-19) pandemic surprised the medical and scientific community because of its characteristic high transmission rate. This has led to the need for reorganization of procedures and the implementation of new approaches to protect medical teams from contamination via aerosols. The latter is of particular importance for those responsible for managing the patient's airway. ${ }^{1}$ Other countries (Italy, China, and Spain) have registered a significant number of infected health professionals. ${ }^{2}$ In addition, during the 2003 severe acute respiratory syndrome (SARS) outbreak in Canada, it was evident that health professionals were at risk of infection, particularly those involved in airway-related

M. Jacob, MD ( $₫) \cdot$ I. Portela, MD · J. Tavares, MD .

S. Moutinho, MD

Anesthesiology Department, Algarve University and Hospitalar

Center, Faro, Portugal

e-mail: migueljacob@gmail.com

Intensive Care Medicine Department, Algarve University and Hospitalar Center, Faro, Portugal

Algarve University and Hospitalar Center, Faro, Portugal

E. Ruivo, MD

Anesthesiology Department, Algarve University and Hospitalar Center, Faro, Portugal

Intensive Care Medicine Department, Algarve University and Hospitalar Center, Faro, Portugal

M. Varela, MDD. Nunez, MD

Intensive Care Medicine Department, Algarve University and

Hospitalar Center, Faro, Portugal

Algarve University and Hospitalar Center, Faro, Portugal procedures such as endotracheal intubation, extubation, and suctioning. ${ }^{3}$ Therefore, it is crucial to minimize the risk of aerosol generation when managing the airway and find protective strategies that can be adopted to mitigate it.

The emission of aerosols through the endotracheal tube (ETT) is a serious form of exposure to the virus that healthcare professionals should consider. Recommendations advise that the ETT be clamped when not connected to a filtered ventilator circuit to reduce aerosol particle dispersion. ${ }^{4}$

Herein, we report the use of a disposable clamp (Figure) consisting of a three-dimensional (3D) printed plastic piece that fits around an ETT allowing clamping/unclamping during intubation/extubation and other procedures such as suctioning. Before videolaryngoscope intubation, we insert

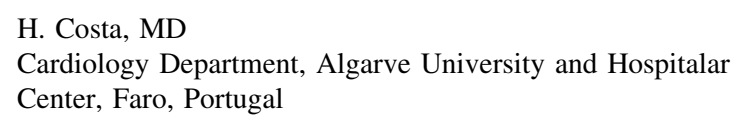

Intensive Care Medicine Department, Algarve University and Hospitalar Center, Faro, Portugal

Algarve University and Hospitalar Center, Faro, Portugal 


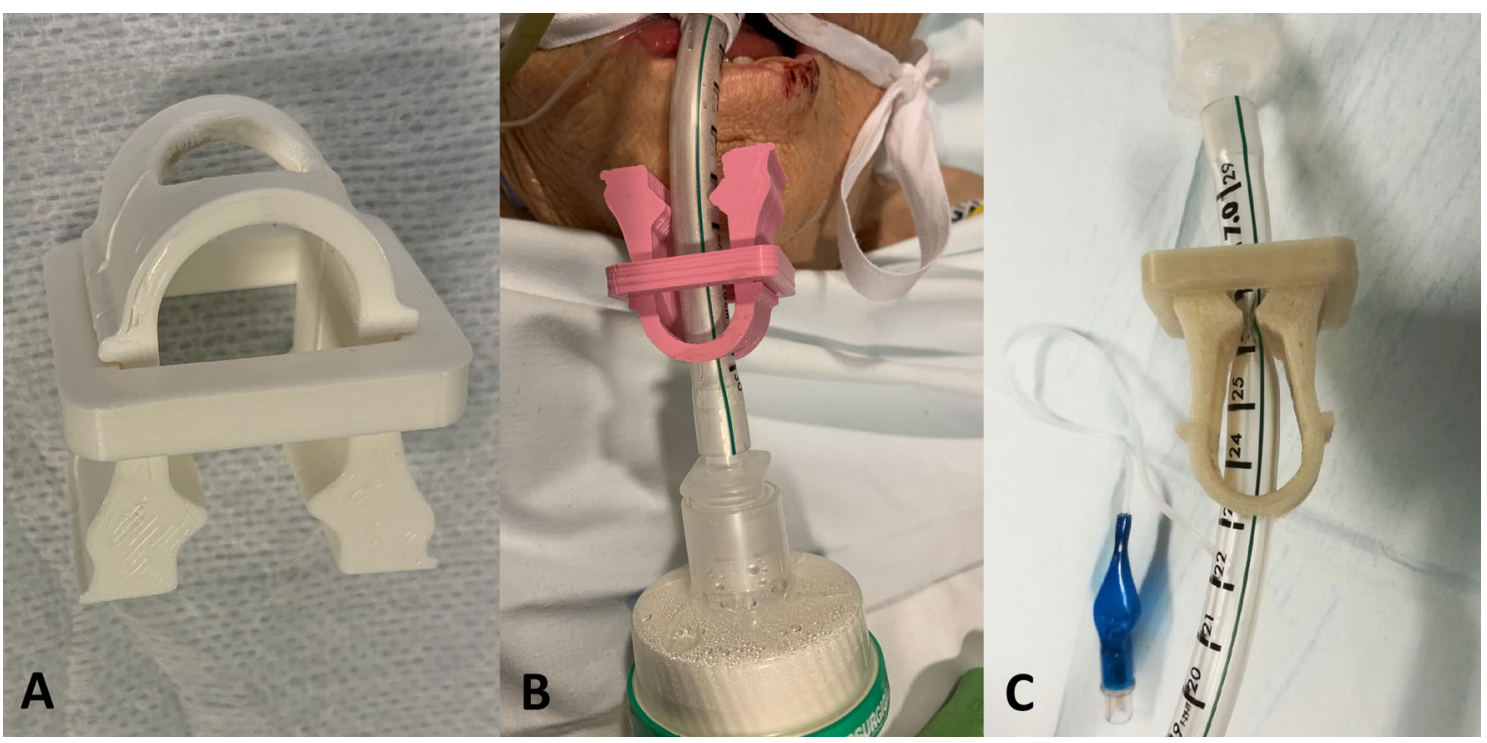

Figure Custom-designed 3D-printed endotracheal tube (ETT) clamp (A) that can be placed on an ETT allowing it to be unclamped (B) and clamped $(\mathrm{C})$ as needed during connection to ventilator circuits and suctioning

the ETT through the device and close the clamp using its integrated clip, only unclamping after connection to the closed circuit of the ventilator. This can be easily done by the same person. Although clamping can also be done with regular surgical forceps, as this proposed clamp always remains attached to the ETT, it makes it practical to use and avoids contamination of multiple forceps, thus reducing the likelihood of cross infection. The ETT clamp was designed by a Portuguese operating room nurse (Mário Gomes; 3D printer file available as an online supplement) ${ }^{\mathrm{A}}$ and it has been produced using polylactic $\mathrm{acid}^{5}$ and a 3D printer. This material is derived from a renewable resource (like corn starch or sugar cane) making it a non-toxic, inexpensive, environmentally friendly product.

Our empirical experience has shown us that with successive use and disinfection, the clamping force may decrease, so we recommend it as a single-patient disposable device. Production is relatively fast and inexpensive, so it has been increasingly used throughout our country. Most intensive care, anesthesiology, and prehospital emergency units have access to the ETT clamp.

This innovative clamp is intended to increase safety, but it does require some training prior to use. It can be used by different health professionals, including doctors, nurses, and respiratory therapists, any time the ETT needs to be disconnected from the ventilator circuit. Medical innovation plays a pivotal role in protecting teams that provide invasive care to infected patients and as the severe acute respiratory syndrome coronavirus 2 (SARS-CoV-2) is highly infectious, the development of additional methods of protection can have added value in airway approach procedures.

\section{Footnote}

A. Dropbox. Available from URL: https://www.dropbox. com/s/j0b6go4nhcv0p81/Clamp\%20TOT.rar?dl=0\& fbclid=IwAR3HAlOHNjemXCHARrReV1TCLguPY rwQ7TX3WkLMweiJdwtpjV3qomBtuo\&file_subpath $=\% 2$ FClamp + TOT $($ accessed May 2020).

\section{Disclosures None.}

\section{Funding statement None.}

Editorial responsibility This submission was handled by Dr. Hilary P. Grocott, Editor-in-Chief, Canadian Journal of Anesthesia.

\section{References}

1. Wu Z, McGoogan JM. Characteristics of and important lessons from the coronavirus disease 2019 (COVID-19) outbreak in China: summary of a report of 72314 cases from the Chinese Center for Disease Control and Prevention. JAMA. 2020. DOI: https://doi. org/10.1001/jama.2020.2648.

2. Lancet T. COVID-19: protecting health-care workers. Lancet. 2020. DOI: https://doi.org/10.1016/S0140-6736(20)30644-9.

3. Caputo KM, Byrick R, Chapman MG, Orser BJ, Orser BA. Intubation of SARS patients: infection and perspectives of healthcare workers. Can J Anesth. 2006;53:122-9. 
4. Cook TM, El-Boghdadly K, McGuire B, McNarry AF, Patel A, Higgs A. Consensus guidelines for managing the airway in patients with COVID-19. Guidelines from the Difficult Airway Society, the Association of Anaesthetists the Intensive Care Society, the Faculty of Intensive Care Medicine and the Royal College of Anaesthetists. Anaesthesia. 2020. DOI: https://doi.org/10.1111/ anae. 15054 .
5. Casalini T, Rossi F, Castrovinci A, Perale G. A Perspective on polylactic acid-based polymers use for nanoparticles synthesis and applications. Front Bioeng Biotechnol. 2019. DOI: https://doi.org/ 10.3389/fbioe.2019.00259.

Publisher's Note Springer Nature remains neutral with regard to jurisdictional claims in published maps and institutional affiliations. 